\title{
ASPEKTY KULTUROWE, KOMPOZYCYJNE I PERCEPCYJNE W OPRACOWANIACH DOTYCZĄCYCH IDENTYFIKACJI CHARAKTERU KRAJOBRAZU NA POZIOMIE LOKALNYM
}

Zarys treści: Zapisany w ustawie krajobrazowej obowiązek sporządzania audytów krajobrazowych jest efektem wdrażania Europejskiej Konwencji Krajobrazowej. Ograniczenie audytu do skali regionalnej (mezoregionów) nie sprzyja identyfikacji lokalnej specyfiki krajobrazu, zwłaszcza w odniesieniu do jego aspektów kulturowych, kompozycyjnych i percepcyjnych. Jeżeli audyt krajobrazowy ma być rzeczywistym narzędziem służącym ochronie krajobrazu w planowaniu przestrzennym, niezbędne jest sporządzanie go również dla jednostek niższego rzędu (mikroregionów), kompatybilnych ze skalą planowania miejscowego, uwzględniając perspektywę człowieka - obserwatora. Aspekty kulturowe, kompozycyjne i percepcyjne w znacznym stopniu decydują o przywiązaniu do miejsca oraz społecznej akceptacji krajobrazu. Powinny one stanowić podstawę prawidłowej jego ochrony i kształtowania na poziomie lokalnym, zwłaszcza w odniesieniu do krajobrazu nie uznawanego za ,priorytetowy”, lecz „zwyczajny”, „,codzienny”. Artykuł stanowi przegląd przykładów zastosowania metod z zakresu architektury krajobrazu, uwzględniających lokalną specyfikę przestrzeni i wykazujących możliwość jej uwzględnienia w planowaniu miejscowym.

Słowa kluczowe: Percepcja krajobrazu, krajobraz Wielkopolski, krajobraz „,codzienny”, audyt krajobrazowy.

\section{Wprowadzenie}

Koncepcja regionalizacji rozumianej jako procedura podziału przestrzeni na jednostki kompleksowo jednorodne pod względem fizjonomii i genezy nie jest nowa. U. Myga-Piątek (2012) opisuje bezpośrednią korelację między tożsamością regionalną a specyficznym krajobrazem kulturowym. Jak zauważył J. Solon (2008, 2014), przy tworzeniu systemów klasyfikacji typologicznej krajobrazu coraz częściej bierze się pod uwagę wskaźniki odnoszące się do czynników antropogenicznych. Nadal jednak zbyt rzadko wykorzystuje się takie kryteria, 
jak struktura osadnictwa i podziały własnościowe, historię terenu i zróżnicowanie regionalne. Na gruncie polskim wyróżniają się: metoda jednostek i wnętrz architektoniczno-krajobrazowych (JARK-WAK), polegająca na wyznaczeniu obszarów homogenicznych pod względem ukształtowania, pokrycia oraz uwarunkowań historycznych (Bogdanowski i in. 1973), metoda wyróżników krajobrazowych (Niedźwiecka-Filipiak 2009), mapa krajobrazów kulturowych Polski autorstwa U. Mygi-Piątek (2012) oraz podejście do regionalizacji krajobrazów kulturowych prezentowane w pracach F. i J. Plitów $(2015,2016)$. Rozwinięciem i uszczegółowieniem klasycznych od dawna stosowanych metod analiz krajobrazu w odniesieniu do konkretnych przypadków problemowych są aktualnie powstające metodologie wykorzystujące dostępne bazy danych i badania terenowe (Senetra 2017; Badora i Jakubiec 2018).

Natomiast w Wielkiej Brytanii i Danii regionalizację krajobrazu przeprowadza się przy użyciu metody Landscape Character Assessment (LCA). LCA ma na celu identyfikację, klasyfikację i charakterystykę jednorodnych jednostek krajobrazowych. Umożliwia ona przeprowadzenie oceny oraz daje podstawę do opracowania strategii dla planowania krajobrazu w różnych skalach (Swanwick 2002). W duńskiej wersji metody LCA podział krajobrazu jest podporządkowany temu, czy dana jednostka wyróżnia się z otoczenia pod względem właściwości kompozycyjno-wizualnych (Stahlschmidt $i$ in. 2017). Integralnym elementem charakterystyki jednostek krajobrazowych jest skala, stopień otwarcia i złożoność krajobrazu oraz czytelność granic krajobrazowych, które wpływają na postrzeganie krajobrazu przez człowieka oraz determinują kompozycję krajobrazową.

Uchwalona w 2015 roku Ustawa o zmianie niektórych ustaw w związu ze wzmocnieniem narzędzi ochrony krajobrazu, została opracowana, aby dostarczyć instrumentów umożliwiających poprawę jakości krajobrazu i zapewniających lepszą jego ochronę (szczególnie tzw. krajobrazów priorytetowych). Jednym z nowych narzędzi jest audyt krajobrazowy, wykonywany obligatoryjnie dla wszystkich województw. Opracowywana obecnie metodologia wykonywania audytu wykorzystuje typologię aktualnych krajobrazów Polski (Chmielewski i in. 2015). Zdaniem autorek, oprócz ogólnej typologii zaproponowanej w metodyce dotyczącej audytu, należy przygotować uzupełniające metody uszczegółowionych analiz krajobrazu odnoszących się do aspektów kulturowych, kompozycyjnych i percepcyjnych. Pozostawienie analiz wyłącznie na proponowanym poziomie ogólności, może uniemożliwić właściwą identyfikację charakteru krajobrazu. Zgodnie z metodą LCA charakter krajobrazu jest rozumiany jako specyficzny, wyrazisty i spójny układ elementów, takich jak ukształtowanie terenu, gleby, roślinność, użytkowanie ziemi, sieć osadnicza i struktury agrarne, który wpływa na to, że dany obszar różni się od innego (Majchrowska 2013).

Pojęcie krajobrazu, w myśl Europejskiej Konwencji Krajobrazowej (EKK), stawia ludzką percepcję na pierwszym miejscu. Definicja EKK jest zbieżna ze 
sposobem rozumienia i interpretowania krajobrazu przez architektów krajobrazu. Podejście to różni się od innych dyscyplin, w których często bada się tylko mierzalne cechy fizjonomiczne krajobrazu, a wyniki przedstawia się za pomocą statystyk. Zależność ta nabiera szczególnego znaczenia przy badaniu krajobrazu „Zwyczajnego”, „codziennego”, czyli krajobrazu kulturowego, związanego z bezpośrednim otoczeniem zamieszkania, traktowanego jako przeciwieństwo dla miejsc chronionych, a więc przestrzeni do zawładnięcia (Wiśniewska 2002). Krajobraz taki, przy wstępnym rozeznaniu, nie posiada cech krajobrazów „priorytetowych" i w statystykach będzie przedstawiał wartość przeciętną. Kluczem dla zachowania ładu przestrzennego i tożsamości krajobrazu jest opracowanie i wdrożenie strategii zarządzania krajobrazem „codziennym”, która uwzględni trudno mierzalny czynnik ludzkiej percepcji i poczucia przynależności do miejsca. Aby w pełni wykorzystać typologię krajobrazu (Chmielewski i in. 2015) - przygotowaną na potrzeby audytu krajobrazowego - niezbędne jest poszukiwanie metod zapewniających przeniesienie wyników na poziom lokalny, właściwy dla planowania przestrzennego (Myga-Piątek 2007).

Celem artykułu jest zaprezentowanie przykładów zastosowania metod i analiz, które uwzględniają lokalną specyfikę krajobrazu i które mogą być przydatne w uzupełnianiu efektów audytów krajobrazowych. Ponadto zwrócenie uwagi na konieczność przeniesienia rezultatów audytu na lokalny poziom planowania przestrzennego. W opracowaniu omówiono trzy odmienne podejścia do analiz krajobrazu, które znajdują zastosowanie w najczęściej występujących sytuacjach: analizy krajobrazu w aspektach wizualnych i kompozycyjnych przy lokalizacji inwestycji; klasyfikacji krajobrazu miasta i ochrony jego walorów oraz analizy na poziomie gminnym (podział na strefy krajobrazowe w SUiKZP w celu przypisania im konkretnych wytycznych planistycznych).

\section{Aspekty kompozycyjne i percepcyjne w ocenach oddziaływania na środowisko}

Aspekty kompozycji i percepcji krajobrazu nabierają szczególnego znaczenia w przypadku lokalizacji nowych inwestycji o przewidywanym dużym oddziaływaniu na krajobraz. Wprowadzając nowe obiekty w krajobrazie trzeba wziąć pod uwagę, że zmiana niektórych jego jednostek znacząco wpłynie na orientację i emocje mieszkańców. Natomiast w innych miejscach lokalizacja nowych elementów nie wywołuje zmian w warstwie znaczeniowej krajobrazu oraz nie zakłóci jego odbioru (Rylke 2017).

W podziałach krajobrazu konieczne jest zidentyfikowanie jednostek o wyraźnie zarysowanej tożsamości, czytelnej kompozycji oraz istotnych powiązaniach i osiach widokowych (np. tak jak w duńskiej wersji metody LCA - Stahlschmidt i in. 2017). W procesie delimitacji jednostek istotną rolę powinny odgrywać 
granice makrownętrz krajobrazowych, stanowiące jednocześnie granice widoczności, a także określenie skali i stopnia otwarcia krajobrazu. Wszystkie te cechy są możliwe do zidentyfikowania tylko na poziomie lokalnym przy wykorzystaniu badań terenowych. Działania te pozwalają na wyróżnienie jednostek krajobrazowych wrażliwych na nowe inwestycje.

Ustalenie wpływu na krajobraz jest częścią oceny oddziaływania przedsięwzięć na środowisko. Wytyczne Regionalnych Dyrekcji Ochrony Środowiska (RDOŚ) dotyczące zakresu badania krajobrazu ściśle wynikają z definicji Europejskiej Konwencji Krajobrazowej, uwzględniając m.in. określenie charakteru i typów krajobrazu. Ponadto integralnym elementem opracowania jest wyróżnienie charakterystycznych cech krajobrazu, na które inwestycja może wpłynąć. Percepcja człowieka-obserwatora została włączona do analiz przez narzucenie pokazania punktów widokowych oraz wizualizacji planowanej inwestycji w panoramach krajobrazowych i ciągach widokowych. Zakres oceny oddziaływania na krajobraz jest zbieżny $\mathrm{z}$ architektoniczno-krajobrazowym podejściem do badania krajobrazu, gdzie na uprzywilejowanym miejscu jest człowiek, który ten krajobraz postrzega. Narzucony przez RDOŚ zakres analiz wyklucza wykonanie ekspertyzy zdalnie, bez badań terenowych. Studia w terenie pozwalają na identyfikację charakteru krajobrazu, poprzez rozpoznanie charakterystycznych układów osadniczych i ich przekształceń, architektury lokalnej, form zieleni wysokiej oraz relacji elementów kulturowych w stosunku do naturalnych, a przede wszystkim powiązań widokowych, na które inwestycja może wpłynąć.

Dla zakresu wymaganego do tej pory przez RDOŚ sprawdzają się metody wchodzące w warsztat badawczy architektury krajobrazu. Dla określenia typów i cech charakterystycznych warto wykorzystać tradycyjną metodę jednostek architektoniczno-krajobrazowych (JARK) (Bogdanowski 1990). Podział krajobrazu na jednostki, jednorodne pod względem fizjonomii i genezy pozwala na zastosowanie ujednoliconej waloryzacji i wytycznych w kontekście zamierzeń inwestycyjnych.

Za przykład opracowania uwzględniającego aspekty kompozycji i percepcji w podziale na jednostki może posłużyć ocena oddziaływania na krajobraz turbin wiatrowych w powiecie brzezińskim (Wilkaniec i in. 2014). Informacje dotyczące charakteru krajobrazu, pozyskane w toku studiów kameralnych i terenowych, zebrano i przeanalizowano przy wykorzystaniu zmodyfikowanej metody JARK. Ze względu na specyfikę opracowywanego zagadnienia, do opisu jednostek dodano punkt „charakterystyka widoczności”. Uwzględnia ona charakter krajobrazu odczytywany pod kątem ekspozycji widokowej, co w znacznym stopniu determinuje percepcję przestrzeni. W „charakterystyce widoczności” wyróżniono „widok ograniczony" (występują sekwencje widoków ograniczonych, np. w terenie zabudowanym) oraz ,widok rozległy” (występują widoki rozległe - panoramiczne, np. w krajobrazie pól uprawnych wielkopowierzchniowych). 
W procesie delimitacji i charakterystyki krajobrazu dla opisywanego przypadku istotny był fakt wyraźnego zróżnicowania pomiędzy makrownętrzem i mikrownętrzem krajobrazowym, w których planowana jest lokalizacja inwestycji (fot. 1-2). Różnica w ocenie krajobrazowej wnętrz zauważalna była na wszystkich etapach prowadzonych prac, począwszy od obserwacji w terenie i wstępnych analiz dostępnych materiałów kartograficznych, poprzez wykonanie map poglądowych zawierających interpretację obserwowanych zjawisk, jak również wygenerowanie wizualizacji i prognoz oddziaływania widokowego inwestycji na krajobraz.
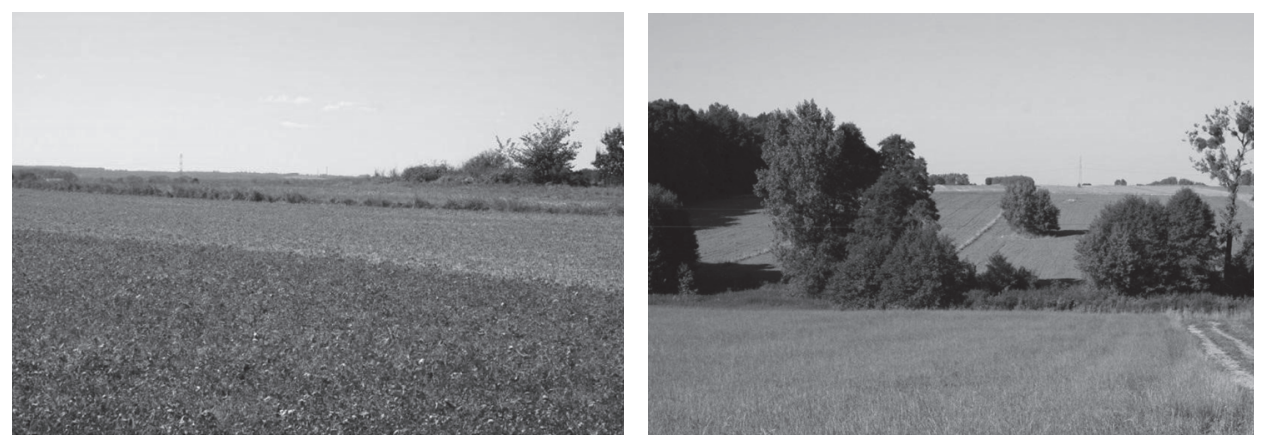

Fot. 1-2. Makrownętrze i mikrownętrze krajobrazowe, w którym planowana była lokalizacja turbin wiatrowych Źródło: archiwum własne.

Jako makrownętrze krajobrazowe potraktowano wydzielony fragment krajobrazu, w obrębie którego położona jest wieś z planowaną lokalizacją inwestycji. Granice makrownętrza wyznaczono za pomocą zasięgu widoczności, który tworzą skupiska zwartej zabudowy, lasy oraz ukształtowanie terenu. Przez mikrownętrza krajobrazowe rozumiano sprzężone ze sobą, za pomocą otwarć widokowych, niewielkie przestrzenie między skupiskami zabudowy siedliskowej i zadrzewieniami śródpolnymi, w sąsiedztwie których planowana jest lokalizacja turbin wiatrowych. W procesie oceny oddziaływania na krajobraz osobno rozpatrywano oddziaływanie turbin wiatrowych na mikro- i makrownętrze krajobrazowe. Nie stwierdzono dominującego lub istotnego wpływu inwestycji na przeważającym obszarze makrownętrza ze względu na występowanie licznych elementów degradujących krajobraz. Wykazano, że charakter mikrownętrza krajobrazowego w wyniku lokalizacji inwestycji zostanie znacząco zmieniony (ryc. 1).

Włączenie w proces delimitacji krajobrazu zagadnień percepcji (m.in. w zakresie zasięgów widoczności) jest kluczowe dla właściwego planowania krajobrazu, oceny pojemności widokowej dla nowych inwestycji oraz zachowania charakterystycznych cech krajobrazu. Powyższy przykład wskazuje, że w zależności od celu (lokalizacja elementów wysokościowych) oraz lokalnej specyfiki (wyraźne 


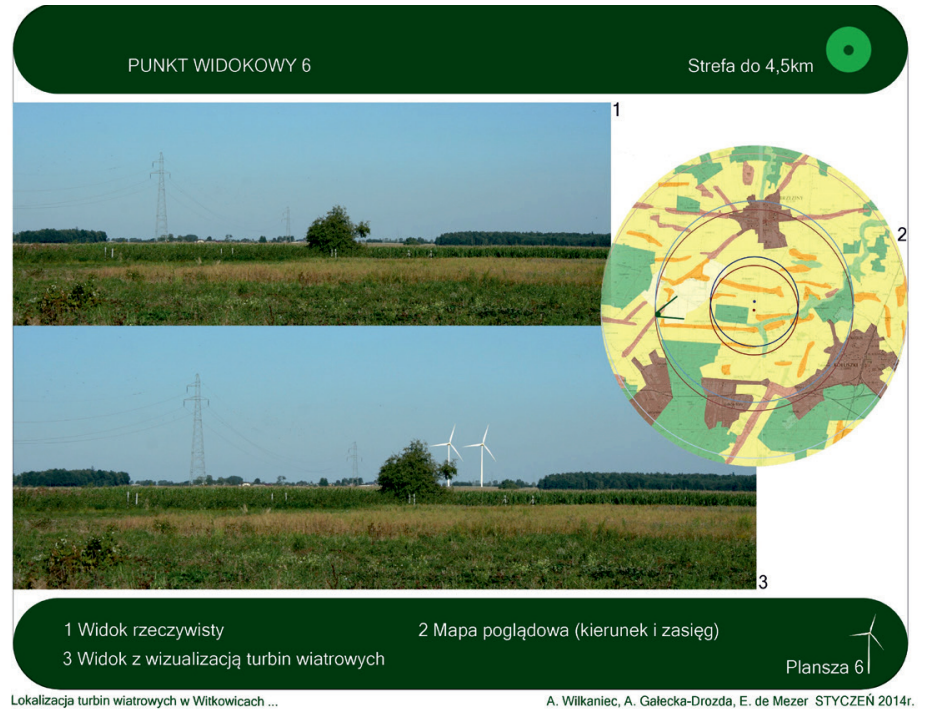

Ryc. 1. Wizualizacja oddziaływania turbiny wiatrowej na krajobraz Źródło: A. Wilkaniec, A. Gałecka-Drozda, E. de Mezer (2014).

zróżnicowanie na mikro- i makrownętrze) konieczne jest stosowanie zmodyfikowanych metod służących rozpoznaniu specyfiki krajobrazu. Trudno stosować jedną, nierozłączną klasyfikację przy badaniu tak zmiennego zjawiska, jakim jest krajobraz, zadaniem badacza jest swobodne dostosowywanie wypracowanych metod do celu badań i zastanej specyfiki przestrzeni.

\section{Aspekty kulturowo-historyczne w analizach krajobrazu miasta}

Miasta są niejednorodnymi i skomplikowanymi przestrzennie tworami, które nie łatwo poddać klasyfikacji krajobrazowej, wobec konieczności znacznej generalizacji. Krajobraz miejski stanowi szczególny przypadek, w którym elementy antropogeniczne i uwarunkowania historyczno-kulturowe w największym stopniu decydują o charakterze krajobrazu (Kłosek-Kozłowska 2007). W odniesieniu do krajobrazu miejskiego kryteria jego klasyfikacji oparte na zagadnieniach kulturowych wydają się być szczególnie ważne (ryc. 2).

Właściwie wykorzystane audyty krajobrazowe, mogłyby stanowić narzędzie umożliwiające skuteczniejszą niż do tej pory ochronę wartości kulturowych istotnych dla krajobrazu miast. Zawarte w nich informacje na temat fragmentów krajobrazu kulturowego mogłyby być przenoszone do opracowań niższego rzędu, aż do najniższego, ale najistotniejszego poziomu planowania miejscowego. Aby audyt był w tym przypadku skutecznym instrumentem, musi spełnić kilka warunków: szczegółowość zastosowanej klasyfikacji i typologii powinna odpowiadać 


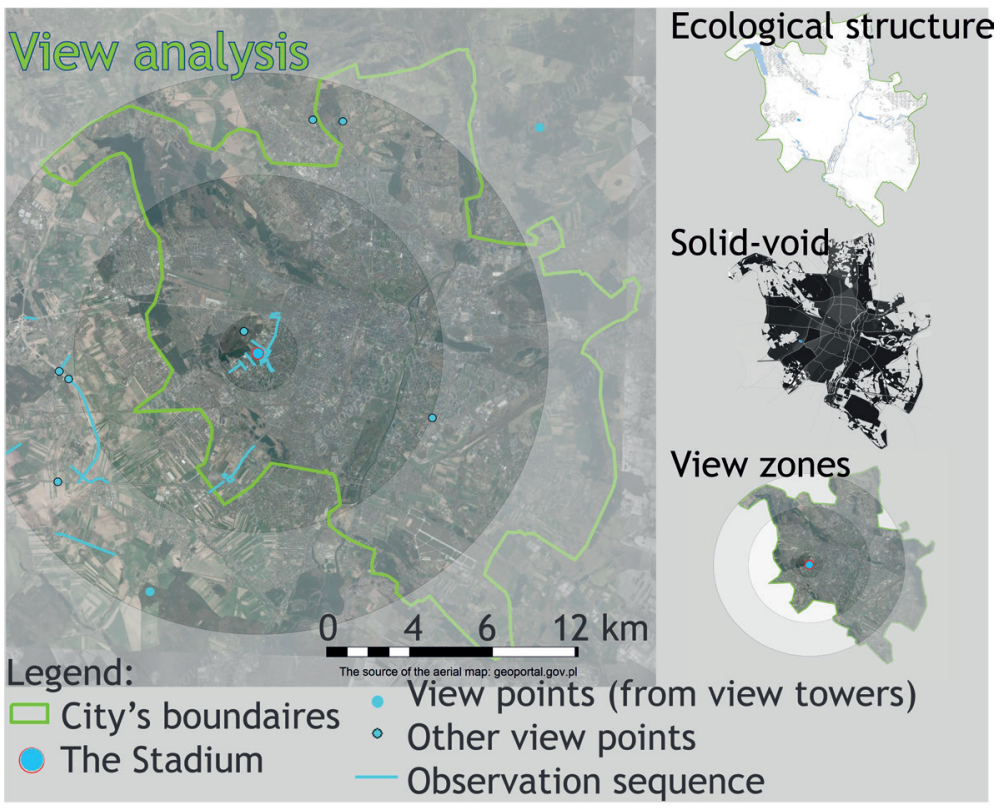

Ryc. 2. Przykład analiz widokowych prowadzonych w przestrzeni miasta. Analizy oddziaływania widokowego Stadionu Miejskiego w Poznaniu Źródło: E. de Mezer, A. Gałecka-Drozda (2013).

poziomowi skomplikowania struktury krajobrazu miejskiego, powinien opierać się na dobrym rozpoznaniu zagadnień historyczno-kulturowych, wykorzystana skala opracowania powinna umożliwiać przeniesienie zawartości audytu do poziomu planowania przestrzennego, co stanowi istotny problem w przypadku opracowań wykonywanych w skali województwa.

Z powodu konieczności generalizacji (skala województwa) w typologii zawartej w propozycji metodologii dotyczącej audytu krajobrazowego dla dużego miasta, trudno jest ując część spośród typów krajobrazu występujących na terenie dużych polskich miast. Dla przykładu, dawne układy ruralistyczne, majątki i tereny rolnicze pozostałe po wsiach wchłoniętych przez miasta ${ }^{1}$, co oczywiste, nie mieszczą się w grupie $\mathrm{C}$ „Krajobrazy kulturowe, w których struktura i funkcja są w pełni ukształtowane przez działalność ludzką”, typ 10 „Wielkomiejskie”. Zaproponowana klasyfikacja typologiczna pozwala na umieszczenie ich $\mathrm{w}$ grupie B typach: 6 „Wiejskie”, 7 „Mozaikowe” lub 8 „Podmiejskie i rezydencjalne” w różnych podtypach. Nie w pełni oddaje to jednak złożony charakter tych krajobrazów - z jednej strony kształtowanych przez rolnictwo oraz wartościowych pod względem kulturowym i historycznym, z drugiej strony pozostających w ścisłych

${ }^{1}$ Jak podają W. Sroka (2014) i P. Krzyk (2009), obecnie ok. 44\% powierzchni polskich miast zajmują użytki rolne. 
relacjach ze współczesnymi elementami przestrzennymi miasta (np. ciągami komunikacyjnymi, kompleksami intensywnej zabudowy o różnych funkcjach). Walory historyczno-kulturowe są ujmowane jako istotna cecha krajobrazów, decydująca o miejscu w klasyfikacji, np. w podtypie C10a „Zespoły urbanistyczne o zachowanych założeniach historycznych” lub B8e „Wielkoobszarowe zespoły pałacowo-parkowe i klasztorne oraz inne komponowane układy architektury, zieleni i wód"2, jednak opis charakterystyki podtypów nie odpowiada charakterystyce struktur takich, jak układy ruralistyczne. Być może przy wykonywaniu audytów pojawianie się problemów z zakwalifikowaniem określonych krajobrazów do proponowanego układu typologicznego można wykorzystać jako wskaźnik obszarów wymagających szczególnej uwagi: niejednorodnych, o skomplikowanym układzie powiązań pomiędzy elementami tworzącymi krajobraz. Wystąpienie tego rodzaju komplikacji mogłoby wskazywać na konieczność objęcia danego obszaru opracowaniem z zastosowaniem rozszerzonej metodologii na poziomie SUiKZP. Ustawa o zmianie niektórych ustaw w zwiąku ze wzmocnieniem narzędzi ochrony krajobrazu przewiduje, że „rekomendacje i wnioski dotyczące kształtowania i ochrony krajobrazów" dotyczyć mają krajobrazów wskazanych jako priorytetowe oraz objętych już ochroną, jednak występujący nadal brak rozporządzenia określającego metody wykonywania audytu pozostawia możliwość dostosowania tych metod do istniejących potrzeb. Rozporządzenie powinno określić „szczegółowy zakres i metodologię audytu krajobrazowego" (Projekt Rozporządzenia... 2016). Być może dobrym rozwiązaniem byłoby uzupełnienie oceny zidentyfikowanych na terenie województwa krajobrazów o uwagi odnoszące się np. do konieczności przeprowadzenia szczegółowych analiz krajobrazowych przy wykonywaniu opracowań planistycznych. Metodami, które można zastosować w tym przypadku są analiza jednostek i wnętrz architektoniczno-krajobrazowych (Bogdanowski i in. 1973), analiza panoram oraz szczegółowa analiza urbanistyczna, określająca jakie obiekty i układy przestrzenne zachowały swoją czytelność i reprezentują wartości historyczne (Dankowska i in. 2016). Pozwoliłoby to pełniej panować nad kształtowaniem krajobrazów, również tych nie uznanych za priorytetowe. W myśl ww. ustawy, za krajobrazy priorytetowe mają zostać uznane krajobrazy szczególnie cenne. Natomiast zdaniem autorek niezwykle ważne byłoby, aby zwiększyć kontrolę również nad krajobrazami o przeciętnej wartości, ale np. ulegających intensywnym przekształceniom.

Przykład odnoszący się do niewystarczająco skutecznej ochrony walorów kulturowych, które mogłyby stać się przedmiotem zainteresowania audytu jako cenne elementy krajobrazu, mogą stanowić układy ruralistyczne i dawne majątki,

\footnotetext{
${ }^{2}$ Podtyp ograniczony jest do tych struktur, które obejmują powierzchnię powyżej 50 ha, co jest zrozumiałe ze względu na skalę audytu, odnoszącą się do województwa, ale może spowodować wyeliminowanie informacji dotyczących mniejszych kompleksów przestrzennych, posiadających jednak istotne znaczenie dla krajobrazu kulturowego.
} 
pozostałych po wsiach włączonych w granice Poznania. Układy te zostały uwzględnione w aktualnie obowiązującym Studium uwarunkowań $i$ kierunków zagospodarowania przestrzennego miasta Poznania (2014, dalej SUiKZP), jednak okazuje się, że informacje na temat ich wartości nie są skutecznie transponowane do poziomu miejscowych planów zagospodarowania przestrzennego. Na rysunku Studium zostały ujęte jako cenne kulturowo fragmenty części siedliskowej dawnych wsi, w niektórych przypadkach wraz z siedzibą majątku, w liczbie 27. Dla poszczególnych kategorii układów ruralistycznych, w zależności od stopnia przekształcenia i czytelności, przewidziano różne formy postępowania przy sporządzaniu planów miejscowych. Dla przykładu, w przypadku dawnych wsi zalecenia zawierają: przeciwdziałanie rozwojowi chaotycznej zabudowy w otoczeniu historycznej wsi, zapewnienie ochrony układu przestrzennemu i autentycznej zabudowy, dostosowanie nowopowstającej zabudowy do tradycyjnych form i kolorystyki budynków historycznych, dążenie do zachowania fragmentów przestrzeni o historycznym charakterze, eksponowanie historycznych dominant i akcentów oraz ochronę ich stref widokowych. Studium przewiduje również zachowanie jako terenów wyłączonych z zabudowy znacznych powierzchni dawnych rozłogów pól należących do części wsi ${ }^{3}$. Zapisy Studium teoretycznie stanowią dobrą podstawę do stworzenia mechanizmów ochronnych, które mogą pojawiać się w miejscowych planach zagospodarowania przestrzennego, jednak postanowienia MPZP pozostawiają wiele wątpliwości. Jedynie pojedyncze opracowania odnoszą się do walorów krajobrazowych i widokowych związanych $\mathrm{z}$ dawnymi wsiami i majątkami. Stopień szczegółowości zapisów jest w przeważającej części MPZP niewielki i niewystarczający, np. orientacyjnie oznaczany jest obszar, który powinien podlegać ochronie, ale brak precyzyjnych zaleceń na czym miałyby polegać działania ochronne. Po części wynika to prawdopodobnie z fragmentaryczności danych wyjściowych jakimi dysponują twórcy planów. Przeważająca większość spośród opisywanych, historycznych układów przestrzennych nie posiada wpisu do rejestru zabytków, co wiązałoby się z gromadzeniem materiałów na ich temat w odpowiednim urzędzie konserwatorskim. Przedstawione w SUiKZP walory poszczególnych układów są ujęte syntetycznie, co wynika z natury tego opracowania. Poznań nie posiada również gminnej ewidencji zabytków, która poszerzyłaby informacje na temat występujących obiektów o walorach historycznych, poza tymi, które posiadają wpis do wojewódzkiego rejestru. Szansą na powstanie zapisów dotyczących cennych fragmentów krajobrazu dawnych wsi zachowanych na terenie miasta, które musiałyby być uwzględniane w powstających dokumentach planistycznych, dawałoby umieszczenie ich w audycie krajobrazowym, np. jako krajobrazów priorytetowych lub wskazanych do opracowania szczegółowych analiz krajobrazowych.

${ }^{3}$ Radojewo, Morasko, Nowa Wieś Górna, Umultowo, północna część Strzeszyna, dolina Głuszynki, okolice Sypniewa i Michałowa. 


\section{Charakter krajobrazu i jego ochrona na przykladzie Studium gminy Rokietnica}

W 2016 roku Rada Gminy Rokietnica, położonej w powiecie poznańskim, uchwaliła Studium uwarunkowań i kierunków zagospodarowania przestrzennego gminy Rokietnica (Uchwała nr XVIII/181/2016 Rady Gminy Rokietnica), w którym przyjęto za kluczowe kierunki działań związane ze stanowieniem ładu przestrzennego na terenie gminy. Dokument powstał jako odpowiedź na postępującą degradację krajobrazu, związaną z rabunkową gospodarką przestrzenną, którą dopuszczała poprzednia wersja studium.

Określenie charakteru krajobrazu, na potrzeby Studium, polegało na wyznaczeniu czterech zróżnicowanych stref krajobrazowych: Urbanizacji, Wschodniej Otuliny Doliny Samicy Kierskiej, Krajobrazu Otwartego, Krajobrazu Rolniczego (Studium... 2016). W strefie Urbanizacji obserwuje się tendencję do akumulacji zabudowy w powiązaniu z infrastrukturą komunikacyjno-transportową oraz techniczną, a założenia polityki przestrzennej przewidują sukcesywne wygaszanie aktywności rolniczych. Strefa Wschodniej Otuliny Doliny Samicy Kierskiej to obszar predysponowany do lokalizacji strategicznych rezerw, dotyczących zabudowy mieszkaniowej, usługowej i techniczno-produkcyjnej. W tej strefie pożądaną tendencją będzie konsolidacja terenów rolniczej produkcji. Dla Strefy Krajobrazu Otwartego Studium ustala ochronę i zachowanie wysokiej klasy gruntów na potrzeby produkcji rolniczej. Ze względów przyrodniczych ochrona ta dotyczy również gleb IVa, IVb i gorszych, bowiem zainwestowanie na tych terenach w najbliższej perspektywie doprowadzi do deprecjacji cennych gruntów rolnych, a także przerwie istotne dla bioróżnorodności i prawidłowego funkcjonowania środowiska przyrodniczego ciągi ekologiczne. Strefa Krajobrazu Rolniczego to teren predestynowany do utrzymania profilu rolniczego. Studium ustala ochrone tego obszaru i zachowanie wysokiej klasy gruntów na potrzeby produkcji rolniczej, z jednej strony przez terytorialne ograniczenie ekspansji inwestycyjnej, z drugiej przez zakaz zabudowy obejmujący zakaz zabudowy siedliskowej.

W opisywanym przypadku Studium autorzy opracowania nie posługiwali się konkretną wcześniej opisaną w literaturze przedmiotu metodą. Natomiast dobrali szereg kryteriów dostosowanych do istniejących lokalnych uwarunkowań i stworzyli procedurę delimitacji poszczególnych stref. Jest to przykład elastycznego podejścia do metodologii przygotowania studium (Barełkowski, Wojtyra 2018). Kryteria wydzielenia stref były różnorodne, związane z identyfikacją charakteru istniejącego krajobrazu. Wśród tych kryteriów znalazły się m.in.: sposób dotychczasowego zagospodarowania, poziom przekształcenia i jakość krajobrazu, jakość gleb, powiązania funkcjonalne pomiędzy poszczególnymi jednostkami osiedleńczymi i elementami systemu przyrodniczego. Przytoczony przykład pokazuje, że klasyfikacje krajobrazu, realizowane w niewielkiej skali w oparciu o elastycznie 
dobrane kryteria pozwalają uchwycić cechy charakterystyczne krajobrazu, decydujące o jego wartości i być przydatne w kształtowaniu polityki przestrzennej samorządów. Przykład Rokietnicy jest o tyle istotny, że opisywana gmina nie posiada wybitnych walorów krajobrazowych w skali województwa, umożliwiających ich ochronę w ramach wyznaczenia krajobrazów priorytetowych. Jednak istnieje możliwość wskazania krajobrazów o wysokiej wartości w skali gminnej oraz takich, które są reprezentatywne dla krajobrazu rolniczego Wielkopolski. Utrzymanie i ochrona jakości tych „codziennych” krajobrazów jest szczególnie istotna z punktu widzenia lokalnej społeczności.

\section{Podsumowanie}

W sytuacji, kiedy audyt krajobrazowy ma być narzędziem służącym ochronie krajobrazu w planowaniu przestrzennym, niezbędne jest dostosowanie jego zapisów i metod tworzenia również do poziomu jednostek niższego rzędu (mikroregionów), a więc kompatybilnych ze skalą planowania miejscowego i uwzględniających perspektywę człowieka-obserwatora. Skala audytu, przewidziana przez ustawodawcę, wykonywanego dla województw, znacząco różni się od skali stosowanej w planowaniu przestrzennym. Może stanowić barierę przy próbach przenoszenia informacji z audytu do SUiKZP i MPZP. Rozwiązaniem mógłby być system różnoskalowych analiz krajobrazu, łączący zaproponowaną typologię krajobrazu w skali województwa $\mathrm{z}$ uszczegółowionymi studiami uwzględniającymi aspekty kulturowe, kompozycje i percepcyjne. Można go oprzeć na hierarchicznym modelu metody LCA, który przewiduje kilka poziomów klasyfikacji krajobrazu. Takie podejście umożliwiałyby przełożenie wizji trójwymiarowej przestrzeni na odpowiednie formuły prawne i zapisy planistyczne oraz ochronę również „codziennych” krajobrazów, pozbawionych wybitnych walorów w skali województwa.

Przedstawione w artykule trzy odmienne podejścia do analiz krajobrazu wskazują na konieczność dostosowania skali i kryteriów klasyfikacji do celu analiz i charakteru krajobrazu. W przypadku analiz oddziaływania widokowego na krajobraz, istotny będzie podział krajobrazu na jednostki różniące się wrażliwością na nową inwestycję oraz rozbudowane analizy widokowe, które pozwolą na rozpoznanie skali i stopnia zwartości krajobrazu (mikro- i makrownętrza). Dla miasta konieczne jest rozbudowanie typologii z uwzględnieniem cech niemiejskich, reliktowych, które w znaczący sposób oddziaływają na postrzeganie krajobrazu oraz włączenie tych elementów do planowania miejscowego. Studia gminne, w zależności od specyfiki krajobrazu, powinny stosować elastyczne kryteria, wynikające $\mathrm{z}$ lokalnych uwarunkowań niemożliwych do rozpoznania na poziomie województwa. 


\section{Literatura}

Badora K., Jakubiec U., 2018, Zastosowanie metodyki audytu krajobrazowego do identyfikacji krajobrazów w skali lokalnej na przykładzie gminy Szczyrk, „Prace Komisji Krajobrazu Kulturowego".

Barełkowski R., Wojtyra B., 2018, Programowanie sanacji przestrzeni wiejskiej. Autorskie mechanizmy planistyczne na rzecz zrównoważonego ksztaltowania obszarów wiejskich, „Acta Universitatis Lodziensis. Folia Geographica Socio-Oeconomica", 32: 31-49.

Bogdanowski J., 1990, Metoda jednostek $i$ wnętrz architektoniczno-krajobrazowych (JARK WAK) w studiach i projektowaniu, Politechnika Krakowska im. Tadeusza Kościuszki, Kraków.

Bogdanowski J., Łuczyńska-Bruzda M., Novak Z., 1973, Architektura krajobrazu, Państwowe Wydawnictwo Naukowe, Kraków.

Chmielewski T.J., Myga-Piątek U., Solon J., 2015, Typologia aktualnych krajobrazów Polski, „Przegląd Geograficzny”, 87(3): 377-408.

Dankowska M., Koter M., Saciuk M., Tomczak A., 2016, Czytelność dawnych układów ruralistycznych $w$ planie współczesnego miasta na przykładzie Łodzi, „Topiarius”, 1: 176-192.

de Mezer E., Gałecka-Drozda A., 2013, Popular culture in the contemporary city spatial structure - view analysis of the Municipal Stadium in Poznań, Poster prezentowany podczas konferencji LE: NOTRE Landscape Forum 2013 Rome.

Kłosek-Kozłowska D., 2007, Ochrona wartości kulturowych miast a urbanistyka, Oficyna Wydawnicza Politechniki Warszawskiej, Warszawa.

Krzyk P., 2009, Obszary rolne jako element systemu przyrodniczego miasta Krakowa, „Problemy Rozwoju Miast”, 3: 47-61.

Majchrowska A., 2013, Doświadczenia innych krajów w identyfikowaniu typów krajobrazowych, [w:] Identyfikacja i waloryzacja krajobrazów - wdrażanie Europejskiej Konwencji Krajobrazowej, Referaty konferencyjne, Generalna Dyrekcja Ochrony Środowiska, Warszawa.

Myga-Piątek U., 2007, Kryteria i metody oceny krajobrazu kulturowego w procesie planowania przestrzennego na tle obowiazujacych procedur prawnych, [w:] Waloryzacja środowiska przyrodniczego w planowaniu przestrzennym „Problemy Ekologii Krajobrazu", 19: 101-110.

Myga-Piątek U., 2012, Krajobrazy kulturowe - aspekty ewolucyjne i typologiczne, Uniwersytet Śląski, Katowice.

Niedźwiedzka-Filipiak I., 2009, Wyróżniki krajobrazu i architektury wsi Polski poludniowo-zachodniej, Wydawnictwo Uniwersytetu Przyrodniczego we Wrocławiu, Wrocław.

Plit F., Plit J., 2015, Hierarchiczna regionalizacja krajobrazów kulturowych. Założenia wstępne, Poziomy 1 i 2: Cywilizacje i domeny kulturowe, „Prace Komisji Krajobrazu Kulturowego", 30: 19-34.

Plit F., Plit J., 2016, Hierarchia regionów krajobrazów kulturowych, Poziomy 3-10: Państwa krajobrazowe i regiony krajobrazowe niższych szczebli, „Prace Komisji Krajobrazu Kulturowego", 31: 9-24. 
Projekt Rozporządzenia w sprawie sporządzania audytów krajobrazowych z dnia 28 września 2016 roku (Dz.U., 2016, poz. 778).

Rylke J., 2017, Teoria i zasady projektowania dla architektów krajobrazu, „Sztuka Ogrodu, Sztuka Krajobrazu", 1(17).

Senetra A., 2017, Zmiany przestrzenno-czasowe wartości estetycznych krajobrazów obszarów pojeziernych na potrzeby ich audytu i ochrony na przykładzie gminy Pozezdrze, „Prace Komisji Krajobrazu Kulturowego”.

Solon J., 2008, Typy krajobrazu kulturowego Polski, „Problemy Ekologii Krajobrazu”, 20.

Solon J., 2014, Przegląd wybranych podejść do typologii krajobrazu, „Problemy Ekologii Krajobrazu", 20: 25-33.

Sroka W., 2014, Definicje oraz formy miejskiej agrokultury, „Wieś i Rolnictwo”, 3(164): 85-103.

Stahlschmidt P., Nellemann V., Primdahl J., Swaffield S., 2017, Landscape Analysis: Investigating the potentials of space and place, Routledge, New York.

Swanwick C., 2002, Landscape Character Assessment. Guidance for England and Scotland, The Countryside Agency, Scottish Natural Heritage.

Wilkaniec A., Gałecka-Drozda A., de Mezer E., 2014, Lokalizacja turbin wiatrowych $w$ Witkowicach - ocena wptywu przedsięwzięcia na krajobraz, Opracowanie wykonane na zlecenie inwestora w związku z koniecznością spełnienia wymogów RDOŚ (maszynopis).

Wiśniewska W., 2002, Krajobrazy codzienne, „Zeszyty Naukowe Politechniki Łódzkiej”, 903, Wydawnictwo Politechniki Łódzkiej, Łódź.

\section{Akty prawne}

Studium uwarunkowań $i$ kierunków zagospodarowania przestrzennego gminy Rokietnica, Załącznik nr 1 do Uchwały nr XVIII/181/2016 Rady Gminy Rokietnica z dnia 29 lutego 2016 roku, http://bip.rokietnica.pl/public/get_file_contents.php?id= 353550 .

Studium uwarunkowań i kierunków zagospodarowania przestrzennego miasta Poznania, Uchwała nr LXXII/1137/VI/2014 z dnia 23 września 2014 roku, http://bip.poznan.pl/ bip/uchwaly/uchwala-nr-lxxii-1137-vi-2014-z-dnia-2014-09-23,53822/.

Ustawa z dnia 24 kwietnia 2015 roku o zmianie niektórych ustaw w związu ze wzmocnieniem narzędzi ochrony krajobrazu (Dz.U., 2015, poz. 774).

\section{CULTURAL, COMPOSITIONAL AND PERCEPTUAL ASPECTS OF LANDSCAPE IN STUDIES REGARDING IDENTIFICATION OF ITS CHARACTER AT THE LOCAL LEVEL OF MANAGEMENT}

Abstract: The obligation to prepare landscape audits registered in the Landscape Act is
the result of the implementation of the European Landscape Convention. Limiting the
audit to the regional scale (mesoregions) is not conducive to the identification of the local
landscape specificity, especially with regard to its cultural, compositional and perceptual
aspects. If landscape audits are to be an effective tool for protection of landscape in spatial
planning, it is necessary also to conduct them for lower-order units (microregions). Such
strategy would be consistent with the scale of local planning and take into account the 
perspective of a human - the observer. The cultural, compositional and perceptual aspects of landscape greatly affect the sense of belonging to a place and its social acceptance. These elements should constitute the basis for its proper protection and development at the local level, especially in relation to the landscape not considered as "priority", but to the "ordinary", "everyday" landscape. The article is an overview of examples of application of landscape architecture methods that take into account the local specificity of space and can be included in local planning.

Keywords: Landscape perception, Greater Poland voivodeship landscape, everyday landscapes, landscape audit.

Mgr inż. Anna Gałecka-Drozda

Katedra Terenów Zieleni i Architektury Krajobrazu

Wydział Ogrodnictwa i Architektury Krajobrazu

Uniwersytet Przyrodniczy w Poznaniu

e-mail: ktzganna@up.poznan.pl

Dr inż. Magdalena Szczepańska

Instytut Geografii Społeczno-Ekonomicznej i Gospodarki Przestrzennej

Wydział Nauk Geograficznych i Geologicznych

Uniwersytet im. Adama Mickiewicza w Poznaniu

e-mail: szmagda@amu.edu.pl

Dr inż. Agnieszka Wilkaniec

Katedra Terenów Zieleni i Architektury Krajobrazu

Wydział Ogrodnictwa i Architektury Krajobrazu

Uniwersytet Przyrodniczy w Poznaniu

e-mail: ktzagawi@up.poznan.pl

Dr Ewa de Mezer

Stowarzyszenie Polskich Architektów Krajobrazu Oddział Wielkopolski e-mail: edemezer@gmail.com 